U-Statistics in Banach Spaces 



\section{U-STATISTICS IN BANACH SPACES}

Yu.V. Borovskikh 
VSP BV

P.O. Box 346

3700 AH Zeist

The Netherlands

C VSP BV 1996

First published in 1996

ISBN 90-6764-200-2

All rights reserved. No part of this publication may be reproduced, stored in a retrieval system, or transmitted in any form or by any means, electronic, mechanical, photocopying, recording or otherwise, without the prior permission of the copyright owner.

\section{CIP-DATA KONINKLIJKE BIBLIOTHEEK, DEN HAAG}

Borovskikh, Yuri V.

U-statistics in Banach spaces / Yuri V. Borovskikh. Utrecht : VSP

With index, ref.

ISBN 90-6764-200-2 bound

NUGI 815

Subject headings: U-statistics / Banach spaces 
Managing Editors: E.V. Cherkashin

International Mathematical Center, Kiev, Ukraine

O.A. Cherkashina

Institute of Mathematics, Kiev, Ukraine

Language Editor: J. Thomas

University of Salford, Manchester, UK 
To

My grandson Anton 
God, Thou great symmetry, Who put a biting lust in me

From whence my sorrows spring,

For all the frittered days

That I have spent in shapeless ways

Give me one perfect thing.

Anna Wickham ("Envoi", 1921) 
